\title{
Does Charity Begin at Home or Overseas?
}

Stephen Knowles ${ }^{1}$ and Trudy Sullivan ${ }^{2}$

Address for correspondence:

Stephen Knowles

Department of Economics

University of Otago

PO Box 56

Dunedin

NEW ZEALAND

Email: stephen.knowles@otago.ac.nz

Telephone: 6434798350 


\title{
Does Charity Begin at Home or Overseas?
}

\author{
Stephen Knowles ${ }^{1}$ and Trudy Sullivan ${ }^{2}$
}

May 2015

\begin{abstract}
We conduct a field experiment to analyse whether a representative sample of the population has a preference for giving money to an international development charity or to a charity helping families in need in the home country. The majority of participants reveal a preference for giving to the local charity, rather than the international development charity. Participants were given the option of commenting on why they chose the charity they did, and we conduct a qualitative analysis of these responses. We also analyse quantitatively whether participants' individual characteristics are correlated with the choice of charity.
\end{abstract}

Keywords: charitable giving, field experiment, local v international giving

JEL codes: C93; D64

Acknowledgments: Funding for this project was provided by the Department of Economics, Otago Business School, University of Otago. We are grateful to Dorian Owen, Maroš Servátka and Jimmy Zeng for helpful comments on the paper.

1. Department of Economics, University of Otago, New Zealand

2. Department of Preventive and Social Medicine, University of Otago, New Zealand

* Corresponding author: Stephen Knowles (stephen.knowles@otago.ac.nz) 


\section{Does Charity Begin at Home or Overseas?}

\section{Introduction}

When giving to charities, do private donors in developed countries have a preference for giving to charities who help people in need in their home country, or to international development charities who help people in need in poor countries overseas? What reasons do people give for choosing to support a charity with a local or overseas focus? We conduct a framed field experiment to analyse this question, using a random sample of the New Zealand population as participants.

To isolate preferences for locally focused or internationally focused charities we observe the choices people make when given the choice of two charities to donate to, with the charities being similar in all respects except that one has a local focus and the other an international focus. To do this, we conduct a field experiment where participants are told that if they complete an online survey, the researchers will make a donation to one of two charities, with the participant choosing the charity. The two charities are World Vision and the Salvation Army. Both are high profile charities, and both are faith-based. The key difference between the two charities is that donations to World Vision help families in need in poor countries overseas, whereas donations to the Salvation Army help people in need in New Zealand. We gave participants the opportunity to comment on why they chose the charity they did, and conduct a qualitative analysis of the reasons given. We also quantitatively analyse whether any of the demographic characteristics of the survey participants (e.g. gender, age, income, whether the participant has travelled to a developing country or not) are correlated with the

choice of charity. We find that 71 percent of participants chose the Salvation Army; the most common reason given for choosing this charity being that charity begins at home. Only two 
demographic characteristics are significantly correlated with the choice of charity: people on high incomes, and those who have donated to international development charities before, are more likely to choose World Vision.

\section{Literature Review}

One approach to analysing whether people have a preference for charities helping people at home or abroad is to study observational data on how much money different charities receive. Atkinson et al (2012) compile a panel data set of private donations to the 200 largest United Kingdom (UK) charities covering the time period 1978-2004 and analyse trends in giving to overseas development. There is significant variation over time in the share of charitable giving that goes to charities with an overseas development focus: the minimum for any one year is just under 20 percent (in the late 1970s) and the maximum just under 40 percent (around the time of the 1985 Ethiopian famine). ${ }^{1}$ These data could be taken to imply that, at least in the UK, people have a preference for giving to local causes but Atkinson et al do not make this inference. ${ }^{2}$ To do so would require controlling for other variables that may affect the choice of charity (e.g. whether a charity is faith-based or secular), as done by Wiepking (2010), a study we discuss below.

An alternative to analysing data drawn from a charity's records, is to use survey data on individuals' reported charitable contributions. This is the approach followed by both Micklewright and Schnepf (2009), and Wiepking (2010). Based on survey data for the UK, Micklewright and Schnepf (2009) find that 10.4 percent of people gave to overseas aid and

\footnotetext{
${ }^{1}$ We are unaware of any research on the share of charitable donations going to international development in New Zealand (the country where we conduct our experiment). However a back of the envelope calculation, based on World Vision New Zealand's financial reports and the fact that World Vision is generally thought to account for approximately half of donations to international development NGOs in New Zealand, would suggest that less than 10 percent of private charitable donations go to international development.

${ }^{2}$ Atkinson et al's (2012) focus is primarily on analysing trends over time in giving to overseas development, not drawing inferences about whether donors prefer to give to local or international causes.
} 
disaster relief in the four weeks prior to the survey, whereas 52.7 percent of people report having given to domestic causes, implying a strong preference for giving to local causes. Micklewright and Schnepf also find the probability of giving to overseas causes relative to local causes is higher for people with a managerial or professional background and for people with a tertiary degree. In addition, people who claim to be very concerned about poverty in developing countries have a higher probability of giving to overseas causes relative to local causes, than do people less concerned about poverty in developing countries.

Wiepking (2010) uses survey data from the Netherlands to analyse which type of people donate to particular types of organisations. The data are drawn from the Giving in Netherlands Panel Survey (GNPS). In this nationally representative survey, people are asked if they have given to any charities, from a list of 64, in the previous 12 months. Sixteen of these charities have an international focus (although this includes Amnesty International whose primary focus is not international development per se). Holding constant other charity attributes (e.g. whether the charity is faith-based or whether it has a focus on children), charities with an international focus are more likely to receive donations. For the sake of comparison, the magnitude of this effect is approximately half the positive effect of having an environmental or animal focus. Therefore, all else equal charities receive more donations if they have an overseas focus, but locally focused charities with certain foci (e.g. the environment) receive more money than international development charities. In terms of who gives to which types of charity, those with an international focus are more likely to receive donations from people who are older, who have an average socioeconomic status, who are religious, who are left-leaning politically and who have confidence in charitable organisations in general.

One reason for the low levels of giving to overseas causes compared to domestic causes found in studies such as Micklewright and Schnepf (2009), and Atkinson et al (2012) could 
be that in many countries there are far more charities with a domestic focus than there are charities with an international focus. This is consistent with Wiepking (2010) who reports that only 16 of the 64 Netherlands charities included in the GNPS data set have an international focus. If people tend to make a small donation to the majority of charities they are approached by, then this would lead to more money being given to local causes. Our methodology controls for this "number of charities" effect by giving people the option of donating to only two charities, one of which has a local focus and the other an international focus.

Micro-level studies based on survey data rely on participants accurately reporting which charities they have donated to. An alternative approach is to use experimental data, based on actual observed behaviour. Preferences for giving to charities with an international focus can, to some extent, be implied from dictator game laboratory experiments where the recipients are charities, if participants are able to choose which of multiple charities their donation goes to. ${ }^{3}$ Most such studies do not report how much money goes to each charity ${ }^{4}$, but one study that does is Eckel and Grossman (2003), whose primary research focus is on the effect of rebates versus matching subsidies on charitable donations. In their study, particpants (university students in the United States) were given the choice of 10 charities to choose from, with three having at least some international focus (Doctors Without Borders, African Christian Relief and Feed the Children). A point the authors do not comment on is that these three charities received 38.8 percent of total donations, suggesting that particpants gave just as much to the charities with an international focus as those with a local focus. Of course, participants may choose the charities they do for reasons other than whether the charity has a

\footnotetext{
${ }^{3}$ In such dictator games participants are given (or, in some cases, perform a task to earn) an endowment of money and are then invited to give some of their money to charity.

${ }^{4}$ This is probably because the researcher is not interested in analysing which charity participants choose, but in analysing differences across treatments such as whether people are more inclined to give if offered a matching subsidy than a rebate. Participants are given a choice of charities to donate to in order to increase average donations, making it easier to observe statistically significant differences across treatments.
} 
local or international focus. For example, a charity may be chosen because it is better known, or because it is concerned with children.

We adopt a similar approach to Eckel and Grossman (2003) but implement a field experiment using the general public as participants instead of a laboratory experiment using students as participants. More importantly, we restrict the choice of charity to two: World Vision and the Salvation Army, therefore controlling for any "number of charities effect”. As noted earlier, these two charities are similar in most respects, except that the former has an international focus and the latter a local focus. Therefore choosing World Vision is likely to indicate a preference for supporting poor families overseas. We also invite participants to give a reason for their choice of charity, which provides information on the extent to which charity choice is driven by considerations other than whether the charity has a local or international focus.

\section{Methodology}

Letters were sent to 3276 participants, chosen at random from the New Zealand electoral roll, inviting them to take part in an online survey on charitable giving, which would take approximately five minutes to complete. Participants were told that if they completed the survey the researchers would make a $\$ 10$ donation to a charity from a research account. ${ }^{5}$ In order to prevent participants from completing the survey more than once, the letter included an alpha-numeric code which had to be entered as one of the survey questions. Participants could choose whether the donation was made to World Vision or the Salvation Army. As discussed in the introduction, these two charities are similar in many respects, with the key difference between them being that the Salvation Army helps families in need in the home

\footnotetext{
${ }^{5}$ Some participants were given one week to complete the survey, others one month and for others no deadline was specified. In a separate paper (Knowles, Servátka and Sullivan, 2015) we analyse whether the different deadline lengths had an effect on response rates.
} 
country, whereas World Vision helps families in need in poor countries overseas. To reinforce this point, the survey explicitly stated that World Vision would use the donation to help families in need in poor countries overseas and that the Salvation Army would use the donation to help families in need in New Zealand. Participants were given the option of commenting on why they chose the charity they did.

The questions on charitable giving included what types of solicitations had prompted participants to donate in the last year (e.g. street appeal, letter), the types of charity they had donated to in the last year (e.g. church or religious group, emergency relief appeals, charities helping people in need overseas) and the payment method used (e.g. paid online, by credit card). The survey also contained a number of demographic questions (e.g. gender, age bracket, income bracket) and questions about whether the participant had travelled overseas and how frequently they follow international news. Of interest is whether there is a correlation between the choice of charity and demographic characteristics such as gender, and other factors such as whether people have travelled to a developing country.

\section{Results}

The overall response rate for the survey is 6.7 percent. Of those who responded, 71 percent chose to donate the $\$ 10$ to the Salvation Army. This indicates that the majority of respondents have a preference for supporting the charity helping people locally, rather than overseas. In the discussion that follows we begin by qualitatively analysing the reasons respondents gave for choosing their charity of choice. We then quantitatively analyse whether the choice of charity is correlated with demographic variables, and factors such as the extent to which they follow world news. 
Of the 215 people who completed the survey, 133 chose to give a reason for their choice of charity. We identified four categories of answers that were commonly given for choosing the Salvation Army. The first is favouring home-based charity, e.g. "charity begins at home” or that "there is a lot of need in New Zealand". The second is familiarity with the Salvation Army. This includes having donated to them before, having observed first-hand the work of the Salvation Army, knowing someone who works for them, or having personally received assistance from them. The third category is people choosing to donate to the Salvation Army because they have donated to World Vision previously so decided they should give to a different charity this time. The fourth category is people who expressed concern about whether money sent overseas would actually get to people in need. This includes responses mentioning administrative costs and the potential for corruption in overseas countries. Responses not fitting any of these four categories are coded as "other". Some people chose to give more than one reason for their choice of charity. In these cases we treat the first answer given as the primary reason, the second as the secondary reason and the third as the tertiary reason. Table One reports the number of responses (primary, secondary and tertiary) for each of the categories described above.

[Table One about here]

The most common reason given for choosing the Salvation Army is that charity begins at home or that there is great need in New Zealand, with over half of respondents giving a primary reason along these lines. The next most common reason given is related to charity recognition. Of this group, eight people (8.5\% of those choosing the Salvation Army) explicitly mention having been personally assisted by the Salvation Army, or seeing firsthand the work the Salvation Army do. Obviously it is more difficult for people to observe first-hand the work done overseas by World Vision. A relatively small number of comments 
are in the "already donated to World Vision" or "concerns about sending money overseas" categories.

We identified three categories of reasons given for choosing World Vision. The first category includes statements to the effect that there is greater need, or less help available, in poor countries overseas than in New Zealand. The second category is familiarity with World Vision. This group includes those who have donated to World Vision previously, respected the charity, etc. Note, however, that no-one mentioned having seen the work of World Vision first-hand. The third category includes those who are concerned that the Salvation Army is too religious. Responses not fitting any of these categories are coded as "other”. Table Two reports the number of responses for each category.

[Table Two about here]

The most common reason, given by over half of those who gave a reason for choosing World Vision, is a statement along the lines that there is "greater need" or "less help available" overseas. Recognition of the charity is the primary reason given by almost a quarter of respondents, with 10 percent choosing World Vision because they perceive the Salvation Army to be too religious. This is an interesting result, given that World Vision is also a faithbased charity, something this small number of participants are perhaps unaware of.

Summing up our results so far, $71 \%$ of respondents chose to support the charity with a domestic focus (the Salvation Army) rather than to support the charity helping poor families overseas (World Vision). The most common reason given for choosing the Salvation Army is 
that charity begins at home, with the most common reason for choosing World Vision the greater need overseas.

We now turn to the quantitative analysis. We used logistic regression analysis to determine whether specific demographic characteristics influence participants' decisions to denote to an international development charity (World Vision) rather than to a charity helping people at home (the Salvation Army). The characteristics (independent variables) used in the logistic regression are gender, age, income, how frequently participants attend religious services, whether they have previously donated to an international development charity, how frequently they follow world news, and whether or not they have travelled to a developing country. More detail on how these variables are measured is given in Table Three. ${ }^{6}$ As discussed in Section 2, Wiepking (2010) found that people in the Netherlands are more likely to donate to an international charity if they are older, of higher socioeconomic status (which we proxy by income ${ }^{7}$ ) and who are more religious. In addition, we hypothesise that people are more likely to give to World Vision if they have previously donated to an international development charity, if they frequently follow overseas news and if they have travelled to a developing country. We have no priors regarding the effect of gender on the choice of charity.

[Table Three about here]

The dependent variable, choice of charity, is equal to 1 if the respondent chooses World Vision and is equal to 0 (the reference category) if they choose the Salvation Army. The

\footnotetext{
${ }^{6}$ The survey asked whether participants had travelled to Africa, Asia, Australia, Central or South America, USA or Canada. There was also an option to list any other countries or regions they had travelled to. Anyone who ticked the box saying they had travelled to Asia, Africa or Central or South America, or listed other developing countries they had travelled to, were treated as having travelled to a developing country.

${ }^{7}$ We also collected data on educational qualifications, but do not include this in the logistic regression as it is highly correlated with income.
} 
results in Table Four, consistent with Wiepking’s (2010) findings for the Netherlands, indicate that respondents earning $\$ 100,000$ and over are 2.73 times more likely to donate to World Vision than respondents earning $\$ 30,000$ or less (although the effect is only marginally significant at the $5 \%$ level). ${ }^{8}$ In addition, respondents who have previously donated to an overseas charity are 3.03 times more likely to donate to World Vision than respondents who have not previously donated to an international development charity. The qualitative results presented in Table One showed that some participants chose to donate to the Salvation Army because they had donated to World Vision before. The regression results, on the other hand, show that, on average, most people keep donating to the same type of charity. No other characteristics, including how frequently people follow world news and whether or not they have travelled to a developing country, have a statistically significant effect on the choice of charity.

[Table Four about here]

\section{Conclusions}

We conduct a field experiment to analyse whether people living in a developed country have a preference for giving to charities helping disadvantaged people in developing countries overseas, or to disadvantaged people in their home country. We find that 71 percent of participants chose the local charity, with the most common reason for doing so being that charity begins at home. Although some participants expressed concern about whether money sent overseas would make it to the intended recipients, this view is shared by a reasonably

\footnotetext{
${ }^{8}$ All references to dollars are to New Zealand dollars. At the time the research was carried out, 1 New Zealand dollar was worth approximately 0.85 US dollars. Mean household income in New Zealand in 2014 was NZ\$88,579 (Statistics New Zealand, 2014).
} 
small proportion of participants. Of those who chose the international development charity, the most common reason given for doing so is that there is greater need overseas. Our quantitative analysis found that people with high incomes are more likely to choose the international development charity, as are those who have given to an international development charity previously.

It appears that for many people charity does begin at home. Our key result is that most people prefer that money be spent to help the needy in their own country, rather than in developing countries. For international development charities to counter this may require reinforcing how great the need is overseas. 


\section{References}

Atkinson, A.B., P.G. Backus, J. Micklewright, C. Pharoah and S.V. Schnepf (2012)

“Charitable giving for overseas development: UK trends over a quarter century”, Journal of the Royal Statistical Society Series A, 175(1):167-190.

Eckel, C.C. and P.J. Grossman (2003) "Rebate versus matching: does how we subsidize charitable contributions matter?”, Journal of Public Economics, 87:681-701.

Knowles, S. M. Servátka, and T. Sullivan (2015) “Procrastination and inattention in charitable giving: a field experiment”, Economics Discussion Paper No. 1501, available online (http://www.otago.ac.nz/economics/otago088472.pdf)

Micklewright, J. and S.V. Schnepf (2009) "Who gives to charitable donations for overseas development?”, Journal of Social Policy, 38(2):317-341.

Statistics New Zealand (2014) Household Economic Survey (Income): Year ended June 2014, available online

(http://www.stats.govt.nz/browse_for_stats/people_and_communities/Households/Household EconomicSurvey_HOTPYeJun14.aspx).

Wiepking, P. (2010) “Democrats support international relief and the upper class donates to art? How opportunity, incentives and confidence affect donations to different types of charitable organizations”, Social Science Review, 39: 1073-1087. 
Table One: Reasons for choosing the Salvation Army

\begin{tabular}{|l|c|c|c|}
\hline Category & $\begin{array}{c}\text { Number of Primary } \\
\text { Responses (\% in } \\
\text { parentheses) }\end{array}$ & $\begin{array}{c}\text { Number of } \\
\text { Secondary } \\
\text { Responses }\end{array}$ & $\begin{array}{c}\text { Number of } \\
\text { Tertiary } \\
\text { Responses }\end{array}$ \\
\hline Charity begins at home & $49(51.6 \%)$ & 4 & 1 \\
\hline Salvation Army recognition & $29(30.5 \%)$ & 9 & \\
\hline $\begin{array}{l}\text { Already donated to World } \\
\text { Vision }\end{array}$ & $9(9.5 \%)$ & 4 & \\
\hline $\begin{array}{l}\text { Concerns about sending } \\
\text { money overseas }\end{array}$ & $6(6.3 \%)$ & & \\
\hline Other & $2(2.1 \%)$ & & \\
\hline
\end{tabular}


Table Two: Reasons for choosing World Vision

\begin{tabular}{|l|c|c|c|}
\hline Category & $\begin{array}{c}\text { Number of Primary } \\
\text { Responses (\% in } \\
\text { parentheses) }\end{array}$ & $\begin{array}{c}\text { Number of } \\
\text { Secondary } \\
\text { Responses }\end{array}$ & $\begin{array}{c}\text { Number of } \\
\text { Tertiary } \\
\text { Responses }\end{array}$ \\
\hline Greater need overseas & $20(52.6 \%)$ & & \\
\hline World Vision recognition & $9(23.7 \%)$ & 2 & \\
\hline Salvation Army too religious & $4(10.5 \%)$ & & \\
\hline Other & $5(13.2 \%)$ & & \\
\hline
\end{tabular}


Table Three: Sample data used for logistic regression

\begin{tabular}{|l|r|c|}
\hline Variables & No. & Percent \\
\hline Dependent variable: Charity & & \\
Salvation Army & 61 & $28.4 \%$ \\
World Vision & 154 & $71.6 \%$ \\
\hline Independent variables: & & \\
Gender: & 79 & $36.7 \%$ \\
Male & 136 & $63.3 \%$ \\
\hline Female & & \\
\hline Age: & 53 & $24.7 \%$ \\
18-35 & 93 & $43.3 \%$ \\
36-65 & 69 & $32.0 \%$ \\
\hline 66 and over & & \\
\hline Household Income: & 42 & $19.5 \%$ \\
\$30,000 or less & 73 & $34.0 \%$ \\
\$30,000-\$70,000 & 42 & $19.5 \%$ \\
\$70,001-\$100,000 & 58 & $27.0 \%$ \\
\hline \$100,001 and over & & \\
\hline Attend religious services: & 168 & $78.0 \%$ \\
Never/infrequently & 47 & $22.0 \%$ \\
\hline Sometimes/regularly & & \\
\hline Previously donated to an international & & \\
development charity: & 131 & $57.7 \%$ \\
No & & \\
Yes & & $32.3 \%$ \\
\hline Follow overseas news: & & \\
Never/once a week to once a month & & \\
Most days & & \\
Every day & & \\
\hline Travelled to developing country : & & \\
(as defined by the World Bank) & & \\
No & & \\
Yes & & \\
\hline
\end{tabular}


Table Four: Results of logistic regression of choice of charity

\begin{tabular}{|c|c|c|c|}
\hline $\begin{array}{l}\text { Choosing to donate to World Vision } \\
\text { (re: Salvation Army) }\end{array}$ & OR & $95 \% \mathrm{CI}$ & $\boldsymbol{P}$ \\
\hline Sex (ref: Male) & & & \\
\hline Female & 0.75 & $(0.38-1.47)$ & 0.40 \\
\hline Age (ref: 18-35) & & & \\
\hline $36-66$ & 0.64 & $(0.25-1.63)$ & 0.35 \\
\hline Over 66 & 0.62 & $(0.25-1.56)$ & 0.31 \\
\hline Income (ref: $\$ 30,000$ or less) & & & \\
\hline$\$ 30,000-\$ 70,000$ & 1.89 & $(0.73-4.88)$ & 0.19 \\
\hline$\$ 70,001-\$ 100,000$ & 1.03 & $(0.31-3.40)$ & 0.97 \\
\hline$\$ 100,001$ and over & 2.73 & $(1.00-7.46)$ & 0.05 \\
\hline $\begin{array}{l}\text { Attend religious services (ref: never/frequently) } \\
\text { Sometimes/regularly }\end{array}$ & 1.31 & $(0.62-2.76)$ & 0.49 \\
\hline $\begin{array}{l}\text { Previously donated to an international } \\
\text { development charity (ref: } \text { no) } \\
\text { Yes }\end{array}$ & 3.03 & $(1.57-5.84)$ & 0.01 \\
\hline $\begin{array}{l}\text { Follow overseas news (ref: once a week or less) } \\
\text { Most days } \\
\text { Every day }\end{array}$ & $\begin{array}{l}0.67 \\
0.49\end{array}$ & $\begin{array}{l}(0.17-2.67) \\
(0.12-1.96)\end{array}$ & $\begin{array}{l}0.57 \\
0.31\end{array}$ \\
\hline $\begin{array}{l}\text { Travelled to developing country (ref: no) } \\
\text { Yes }\end{array}$ & 1.34 & $(0.68-2.66)$ & 0.40 \\
\hline
\end{tabular}

$\mathrm{N}=215$; OR, odds ratio; CI, confidence interval. 